\title{
EVALUASI PENGGUNAAN ANTIBIOTIK PADA PASIEN ISPA NON-PNEUMONIA ANAK RAWAT JALAN DI RSUD KOTA TANGERANG SELATAN
}

\author{
Nurwulan Adi Ismaya \\ Sekolah Tinggi Ilmu Kesehatan Kharisma Persada \\ Tangerang Selatan, 15417 \\ E-mail: wulan.ismaya@gmail.com
}

\begin{abstract}
ABSTRAK
Latar Belakang : Infeksi Saluran Pernapasan Akut masih merupakan masalah kesehatan utama yang banyak ditemukan di Indonesia dan merupakan penyebab kematian paling tinggi pada anak balita. Tujuan Penelitian : Mengetahui rasionalitas penggunaan antibiotik pada pasien Infeksi Saluran Pernafasan Akut (ISPA) nonpneumonia anak di Rumah Sakit Umum Daerah Kota Tangerang Selatan. Metode : Penelitian ini termasuk dalam kategori deskriptif retrospektif yaitu berdasarkan data yang sudah ada dan tertulis dalam catatan medis pasien. Pada Tahun 2016 terdapat 130 pasien anak yang masuk dalam kriteria penelitian. Hasil Penelitian : Hasil penelitian menggunakan kategori Gyssens menunjukan penggunaan antibiotik yang sudah rasional sebanyak 63 pasien $(49,2 \%)$, tidak tepat dosis 54 pasien $(40,8 \%)$, pemberian antibiotik terlalu lama 8 pasien $(6,2 \%)$, dan terdapat antibiotik yang lebih efektif 5 pasien $(3,8 \%)$. Diskusi : Sebanyak 63 pasien dikatakan sudah rasional berdasarkan kriteria yang sudah tercantum dalam metode Gyssens yaitu kriteria antibiotik rasional (kategori 0). Kesimpulan : berdasarkan hasil penelitian ini, kerasionalan penggunaan antibiotik pada pasien Infeksi Saluran Pernafasan Akut (ISPA) non-pneumonia anak di Rumah Sakit Umum Daerah Kota Tangerang Selatan 49,2\% sudah rasional.
\end{abstract}

Kata kunci : Antibiotik, anak, Gyssens

\begin{abstract}
Background: Acute Respiratory Tract Infection is still a major health problem commonly found in Indonesia and it cause of death among children under five. Objective: To know rationality of antibiotic usage in patient of Acute Respiratory Infection (ISPA) of child non-pneumonia at Tangerang Selatan Regional General Hospital. Methods: This study belongs to a retrospective descriptive category based on patient's medical records. In the year 2016 there are 130 pediatric patients who entered the study criteria. Results: The results of the study using the Gyssens category showed rational use of antibiotics of 63 patients (49.2\%), inappropriate doses of 54 patients (40.8\%), antibiotics for 8 patients (6.2\%), and there are more effective antibiotics 5 patients (3.8\%). Discussion: A total of 63 patients are rational based on Gyssens method of rational antibiotic (category 0). Conclusion: Based on the results of this study, the rationale of antibiotic use in patients with Acute Respiratory Infection (ARI) of non-pneumonia of children in Tangerang Selatan Regional General Hospital $49.2 \%$ was rational.
\end{abstract}

Keywords : Antibiotic, children, Gyssens

\section{LATAR BELAKANG}

Infeksi Saluran Pernafasan Akut (ISPA) adalah penyakit infeksi akut yang menyerang salah satu bagian atau lebih dari saluran nafas mulai dari hidung hingga alveoli, seperti sinus, rongga 
telinga tengah dan pleura. ISPA masih merupakan masalah kesehatan utama yang banyak ditemukan di Indonesia dan merupakan penyebab kematian paling tinggi pada anak balita (Rustandi, 2011).

Menurut Rudan et al Bulletin WHO 2008 Infeksi Saluran Pernafasan Akut (ISPA) merupakan penyakit yang sering terjadi pada anak. Penyakit ini sering terjadi pada balita yang diperkirakan 0,29\% per tahun di negara berkembang, sedangkan di negara maju diperkirakan $0,05 \%$ per tahun. Hal ini menujukan terdapat 156 juta kasus per tahun, dimana 151 juta $(96,7 \%)$ kasus Infeksi Saluran Pernafasan Akut (ISPA) terjadi di negara berkembang. Kejadian terbanyak terjadi di negara India (43 juta), China (21 juta), Pakistan (10 juta), dan Bangladesh, Nigeria, Indonesia masing-masing 6 juta kejadian penyakit Infeksi Saluran Pernafasan Akut (ISPA). Kejadian yang terjadi di masyarakat $7-13 \%$ termasuk kejadian yang berat dan memerlukan perawatan di rumak sakit. Kejadian batuk pilek pada anak di Indonesia diperkirakan sebesar 3 sampai 6 kali setahun. Sebagai kelompok penyakit, Infeksi Saluran Pernafasan Akut (ISPA) merupakan penyebab utama kunjungan pasien di sarana kesehatan. Sebanyak 40\% sampai 60\% kunjungan berobat di Puskesmas dan $15 \%$ sampai $30 \%$ kunjungan berobat di bagian Rawat Jalan dan Rawat Inap Rumah Sakit.

Berdasarkan hasil RISKESDA 2002 sampai dengan 2003 dilaporkan bahwa Angka Kematian Balita (AKBA) di Indonesia sekitar 35 per 1000 kelahiran hidup. Pada anak berusia dibawah 5 tahun tingkat kematian diperkirakan setiap tahunnya sebanyak 2 per 3 kematian tersebut adalah bayi. Hasil keseluruhan kematian yang disebakan oleh Infeksi Saluran Pernafasan Akut (ISPA) mencakup 20\% sampai 30\% (Kementerian Kesehatan RI, 2011).

Penyakit infeksi saluran pernafasan akut (ISPA) khususnya non-pneumonia (pernafasan akut atas) merupakan jumlah kasus yang menurut hasil RISKESDA tahun 2013 menunjukan bahwa jumlah kasus ISPA yang tertinggi pada kelompok anak umur 1-4 tahun (25,8\%), meskipun kategori ISPA ini masih di bawah Infeksi Saluran Pernafasan Akut Atas (ISPAa), ISPA bagian bawah (non-pneumonia) dapat menjadi awal dari penyebab infeksi yang dapat memperburuk keadaan pasien sehingga dapat menyebabkan kematian pada anak.

Penyakit Infeksi Saluran Pernafasan Akut (ISPA) dalam pengobatannya juga harus diperhatikan dengan benar, salah satu contoh dalam penggunaan antibiotik yang mempunyai peranan penting dalam proses penyembuhan infeksi. 
Permasalahan yang sering terjadi dalam peresepan antibiotik pada anak seperti tidak tepatnya dosis yang diterima pasien anak. Tidak tepatnya dosis yang diterima pasien dapat terjadi kelebihan dan kekurangan dosis, apabila dosis terlalu tinggi dapat menyebabkan toksisitas pada pasien sedangkan dosis terlalu rendah antibiotik tidak dapat mencapai efek terapi dan hanya akan menyebabkan resistensi. Sehingga pengobatan yang ideal untuk anak harus benar-benar memperhatikan kondisi anak tersebut seperti umur, kondisi psikologis, dan berat badan anak. Kondisi tubuh anak memiliki respon yang berbeda terhadap obat dibandingkan dengan tubuh orang dewasa.

Berdasarkan hasil survei awal yang dilakukan pasien ISPA non-pneumonia anak di RSUD Kota Tangerang Selatan pada tahun 2016 diketahui dengan jumlah penderita ISPA non-pneumonia sebanyak 135 pasien. Di RSUD Kota Tangerang Selatan belum pernah diadakan penelitian tentang evaluasi penggunaan antibiotik untuk pasien Infeksi Saluran Pernafasan Akut (ISPA) non-pneumonia anak. Sehingga berdasarkan uraian di atas penelitian ini bertujuan untuk mengevaluasi penggunaan obat antibiotik pada pasien Infeksi Saluran Pernafasan Akut (ISPA) non-pneumonia anak di RSUD Kota Tangerang Selatan di Instalasi Rawat Jalan pada Tahun 2016.

\section{METODE}

Penelitian ini termasuk dalam kategori deskriptif retrospektif yaitu berdasarkan data yang sudah ada dan tertulis dalam catatan medis pasien. Pada Tahun 2016 terdapat 130 pasien anak yang masuk dalam kriteria penelitian. Data dianalisis dengan menggunakan metode Gyssens.

Desain yang digunakan adalah Cross Sectional, yaitu pengumpulan data variabel untuk mendapatkan gambaran rasionalitas penggunaan antibiotik pada pasien ISPA non-pneumonia pada anak. Data diambil dari bagian rekam medik RSUD Kota Tangerang Selatan pada Tahun 2016.

\section{HASIL}

\section{Data Demografi Pasien}

\begin{tabular}{cccc}
\multicolumn{4}{c}{ Tabel 1 Data Demografi Pasien } \\
\hline No & Variabel & Jumlah N = 130 \\
\hline & N & $\%$ \\
\hline & & Berdasarkan Usia \\
\hline $\mathbf{1}$ & $0-5$ (Balita) & 62 & 47,7 \\
\hline $\mathbf{2}$ & $5-14$ (Anak) & 68 & 52,3 \\
\hline & & Berdasarkan Jenis Kelamin \\
\hline $\mathbf{3}$ & Laki-Laki & 60 & 46,2 \\
\hline $\mathbf{4}$ & Perempuaan & 70 & 53,8 \\
\hline
\end{tabular}


Sumber: Data rekam medik RSUD Kota Tangerang Selatan tahun 2016.

\section{a. Berdasarkan Usia}

Berdasarkan data tabel 1, dapat diketahui pasien Infeksi Saluran Pernafasan Akut (ISPA) nonpneumonia yang terjadi pada kelompok balita (usia 0 sampai 5 tahun) sebanyak 62 pasien $(47,7 \%)$ dan kelompok anak (usia 5 tahun sampai 14 tahun) sebanyak 68 pasien $(52,3 \%)$.

\section{b. Berdasarkan Jenis Kelamin}

Berdasarkan tabel 4.1, pasein yang telah dikelompokkan sesuai jenis kelamin, dari 130 pasien terdapat 60 (46,2\%) pasien laki-laki dan 70 $(53,8 \%)$ pasien perempuan. Berdasarkan tabel di atas, penderita Infeksi Saluran Pernafasan Akut (ISPA) non-pneumonia paling banyak terjadi pada perempuan.

2. Penggunaan Antibiotik Berdasarkan Jumlah

Tabel 2 Penggunaan Antibiotik Berdasarkan Jumlah

\begin{tabular}{llcc}
\hline No & Nama Obat & Jumlah & Persentase (\%) \\
\hline 1 & Sefiksim & 67 & 51,3 \\
\hline 2 & Azitromisin & 40 & 30,7 \\
\hline 3 & Sefadroksil & 21 & 16,2 \\
\hline 4 & Eritromisin & 1 & 0,77 \\
\hline 5 & Claneksi & 1 & 0,77 \\
\hline & Total & 130 & 100
\end{tabular}

Keterangan $\%=$ Persentase dihitung dari jumlah total obat

Berdasarkan hasil penelitian pada tabel 2, menunjukan bahwa antibiotik yang paling banyak digunakan sebagai terapi ISPA nonpneumonia pada anak adalah sefiksim sebanyak 67 antibiotik (51,3\%). Sefiksim merupakan golongan sefalosporin golongan III yang memiliki sifat bakterisid dan berspektrum luas terhadap mikroorganisme gram postif dan gram negatif. Sefiksim ini juga merupakan pilihan untuk pengobatan faringitis dan tosilitis yang disebabkan oleh Streptococus pyogenes.

Pada urutan kedua antibiotik yang paling banyak digunakan adalah azitromisin sebanyak 40 antibiotik (30,7\%). Azitromisin merupakan golongan makrolida memiliki aktivitas yang lebih poten terhadap bakteri gram negatif dengan volume distribusi lebih luas dan waktu paruh yang lebih panjang dan sesuai dengan pustaka juga dapat untuk pengobatan Infeksi Saluran 
Pernafasan Akut (ISPA) atas maupun bawah.

Urutan ketiga antibiotik yang paling banyak digunakan adalah sefadroksil sebanyak 21 antibiotik (16,2\%). Sefadroksil merupakan antibiotik golongan sefalosporin golongan I yang aktif terhadap bakteri gram positif dan gram negatif serta bakterisid. Urutan keempat adalah antibiotik eritromisin sebanyak 1 antibiotik $(0,77 \%)$ dan urutan kelima antibiotik claneksi sebanyak 1 antibiotik $(0,77 \%)$.

3. Berdasarkan Diagnosa dan Penyakit Penyerta

Tabel 3 Data Diagnosa dan Penyakit Penyerta

\begin{tabular}{llcc}
\hline No & Penyakit Utama dan Penyakit Penyerta & Jumlah & $\begin{array}{c}\text { Persentase } \\
(\mathbf{\%})\end{array}$ \\
\hline 1 & Faringitis & 81 & 62,3 \\
\hline 2 & Tonsilitis & 31 & 23,8 \\
\hline 3 & Faringitis + Pneumonia Atipikal & 8 & 6,2 \\
\hline 4 & Faringitis + Bronkhitis & 5 & 3,8 \\
\hline 5 & Faringitis + Dispepsia & 2 & 1,5 \\
\hline 6 & Faringitis + Asma Bronkhial & 1 & 0,8 \\
\hline 7 & Faringitis + Konjungtivitis & 1 & 0,8 \\
\hline 8 & Faringitis + Ikteria & 1 & 0,8 \\
\hline & Total & 130 & 100 \\
\hline
\end{tabular}

Sumber:Data rekam medik RSUD Kota Tangerang Selatan periode tahun2016.

Berdasarkan tabel 3, pasien anak yang menderita faringitis tanpa diagnosa lain sebanyak $81(62,3 \%)$ pasien. Faringitis merupakan peradangan pada mukosa faring banyak dijumpai pada anak usia 4-15 tahun. Tanda-tanda awal faringitis berupa demam, nyeri untuk menelan, dan mual yang dialami penderita.Pada tabel di atas terdapat $31 \quad(23,8 \%)$ pasien tonsilitis (amandel). Penyakit ini merupakan infeksi pada amandel yang terkadang mengakibatkan sakit tenggorokan, nyeri ketika untuk menelan, dan disertai demam.Penyebab radang amandel adalah bakteri Streptokokus beta hemolitikus grup A, Haemophilus influenza, dan dari golongan bakteri pneumokokus dan stafilokokus.

Pada tabel diatas terdapat 8 $(6,2 \%)$ pasien faringitis dengan pneumonia atipikal. Pneumonia atipikal merupakan infeksi pada bagian ujung bronkhiol dan alveoli yang dapat disebabkan oleh berbagai patogen seperti bakteri, jamur, virus, dan parasit. Pneumonia atipikal ini sering disebabkan oleh bakteri Mycoplasma, Legionella, dan Clamydia. Penyakit ini dapat terjadi 
karena penyakit penyerta pernafasan lain dan juga kelainan pada paru serta penyakit ini yang disebabkan oleh virus banyak dijumpai pada bayi dan anak.

Pada tabel di atas terdapat 5 $(3,8 \%)$ pasien faringitis dengan bronkhitis. Bronkhitis merupakan gejala peradangan pada daerah trakheobronkhial. Pada anak dikenal bronkhiolitis, penyakit ini dengan faringitis sering terjadi bersamaan. Faringitis ditandai dengan nyeri ketika menelan dan sedangkan bronkhitis ditandai dengan batuk yang menetap bertambah parah pada malam hari serta biasanya di sertai sputum, biasanya disebabkan oleh rhinovirus, lesu, lelah, dan demam pada suhu tubuh yang rendah disebabkan oleh virus influenza, adenovirus, atau infeksi bakteri.

Pada tabel di atas terdapat 2 $(1,5 \%)$ pasien faringitis dengan dispepsia. Dispepsia merupakan rasa tidak nyaman yang berasal dari daerah abdomen bagian atas. Rasa tidak nyaman tersebut dapat berupa salah satu atau beberapa gejala berikut; nyeri epigastrium, rasa terbakar di epigastrium, rasa penuh setelah makan, cepat kenyang, mual, muntah, dan sendawa.Penyakit ini dapat didiagnosa dispepsia dengan keluhan tersebut setidaknya selama tiga bulan terakhir (Futagami $\mathrm{S}$ and Shimpuku M, 2011).

Pada tabel di atas terdapat 1 $(0,8 \%)$ pasien faringitis dengan asma bronkhial. Asma bronkhial merupakan peradangan kronik saluran pernafasan yang menyebabkan hiperaktivitas bronkus terhadap berbagai rangsangan yang ditandai dengan gejala episodik berupa mengi, batuk, sesak nafas, dan rasa berat di dada terutama pada malam hari dan bersifat reversibel.

Pada tabel di atas terdapat 1 $(0,8 \%)$ pasien faringitis dengan konjungtivitis. Konjungtivitis merupakan peradangan pada konjungtiva dan penyakit ini adalah penyakit mata yang paling umum di dunia. Penyakit ini dpat disebabkan oleh bakteri maupun virus dan faktor-faktor lingkungan lain yang mengganggu (Vaughan, 2010).

Pada tabel diatas terdapat 1 $(0,8 \%)$ pasien dengan ikteria. Ikteria merupakan perwanaan kuning pada kulit dan mukosa karena terjadinya peningkatan kadar bilirubin, ikteria akan tampak ketika nilai bilirubin $>5 \mathrm{mg} / \mathrm{dL}$. Ikteria lebih mengacu pada gambaran klinis berupa pewarnaan kuning pada kulit, sedangkan hiperbilirubinemia lebih 
4. Evaluasi Rasionalitas Antibiotik

Tabel 4. Hasil Evaluasi Metode Gyssens

\begin{tabular}{llcc}
\hline No & \multicolumn{1}{c}{ Kategori } & $\begin{array}{c}\text { Jumlah } \\
\text { Kasus }\end{array}$ & $\begin{array}{c}\text { Persentase } \\
(\mathbf{\%})\end{array}$ \\
\hline 0 & $\begin{array}{l}\text { Penggunaan antibiotik tepat dan } \\
\text { bijak }\end{array}$ & 63 & 48,5 \\
\hline I & $\begin{array}{l}\text { Penggunaan antibiotik tidak tepat } \\
\text { waktu }\end{array}$ & 0 & 0 \\
\hline II A & $\begin{array}{l}\text { Penggunaan antibiotik tidak tepat } \\
\text { dosis }\end{array}$ & 54 & 41,5 \\
\hline II B & $\begin{array}{l}\text { Penggunaan antibiotik tidak tepat } \\
\text { interval pemberian }\end{array}$ & 0 & 0 \\
\hline II C & $\begin{array}{l}\text { Penggunaan antibiotik tepat rute } \\
\text { pemberian }\end{array}$ & 0 & 0 \\
\hline III A & Penggunaan antibiotik terlalu lama & 8 & 6,2 \\
\hline III B & $\begin{array}{l}\text { Penggunaan antibiotik terlalu } \\
\text { singkat }\end{array}$ & 0 & 0 \\
\hline IV A & Ada antibiotik yang lebih efektif & 5 & 3,8 \\
\hline IV B & Ada antibiotik yang kurang toksik & 0 & 0 \\
\hline IV D & $\begin{array}{l}\text { Ada antibiotik yang spektrumnya } \\
\text { lebih sempit }\end{array}$ & 0 & 0 \\
\hline V & $\begin{array}{l}\text { Tidak ada indikasi penggunaan } \\
\text { antibiotik }\end{array}$ & 0 & 0 \\
\hline IV & $\begin{array}{l}\text { Data rekam medik yang tidak } \\
\text { lengkap dan tidak dapat dievaluasi }\end{array}$ & 0 & 0 \\
\hline & $\quad$ Jumlah & $\mathbf{1 3 0}$ & $\mathbf{1 0 0}$ \\
\hline
\end{tabular}

Keterangan $\%=$ Persentase dihitung dari jumlah total pasien

Berdasarkan evaluasi Gyssens pada tabel 4., menunjukan terdapat 63 (48,5\%) kasus antibiotik sudah rasional (kategori 0), selanjutnya terdapat 54 (41,5\%) kasus penggunaan antibiotik tidak tepat dosis (kategori IIA), kemudian terdapat $8(6,2 \%)$ kasus penggunaan antibiotik terlalu lama (kategori IIIA), dan terdapat 5 (3,8\%) kasus ada antibiotik yang lebih efektif untuk pasien (kategori IVA).

\section{DISKUSI}

Dari 130 pasien sebanyak 63 pasien dikatakan sudah rasional berdasarkan kriteria yang sudah tercantum dalam metode Gyssens yaitu kriteria antibiotik rasional (kategori 0). Selanjutnya terdapat 54 (41,5\%) kasus penggunaan antibiotik tidak tepat dosis (kategori IIA), kemudian terdapat $8(6,2 \%)$ kasus penggunaan antibiotik terlalu lama (kategori IIIA), dan terdapat 5 $(3,8 \%)$ kasus ada antibiotik yang lebih efektif untuk pasien (kategori IVA). Masalah - masalah penggunaan obat dibahas berdasarkan pustaka Pharmaceutical care untuk penyakit infeksi saluran pernafasan, 2005 dan Pharmacotherapy Handook Ninth Edition, 2008. 


\section{KESIMPULAN}

Berdasarkan hasil penelitian ini, kerasionalan penggunaan antibiotik pada pasien Infeksi Saluran Pernafasan Akut (ISPA) non-pneumonia anak di Rumah Sakit Umum Daerah Kota Tangerang Selatan 49,2\% sudah rasional.

\section{DAFTAR PUSTAKA}

Barbara G. Wells, Joseph T. Dipiro, Terry

L. Schwinghammer, Cecily V. Dipiro. Pharmacotherapy Handbook. Ninth Edition. 2008.

Depaertemen Kesehatan RI. Sistem Kesehatan Nasional. Jakarta. 2009.

Departemen Kesehatan RI. Pharmaceutical care untuk Penyakit Infeksi Saluran Pernafasan. 2005.

Direktorat Jendral Pengendalian Penyakit dan Penyehatan Lingkungan, 2012. Pedoman Pengendalian Infeksi Saluran Pernafasan Akut. Jakarta: Kemenkes RI.

Drug Information Handbook Edition 7th: American Pharmacists Assocation. 2008-2009.

Futagami S, Shimpuku M, Yin Y, et al. Phatophisiology of functional dyspepsia. J Nippon Med Sch. 2011.

Garcia-Ferrer, F.J., Schwab, LR., Shetlar, D.J. Konjungtiva. Dalam: Vaughan \& Asbury. Oftalmologi Umum. Edisi 17. Jakarta, 2010.
Gyssens IC, Auidit for monitoring the quality of antimicrobial prescription. I.M. Goul, Jos W.M. van der Meer, editor, Antibiotics Policies: Theory and practice. New York: Spinger US;2005. 197-226.

Habisuan, W.S. 2010. Karakteristik Penderita Malaria Dengan Parasit Positif Pada Anak Diklinik Malaria Rayon Panyabungan Kabupaten Mandailing Natal Tahun 2009. Fakultas Kesehatan Masyarakat. Universitas Sumatra Utara, Medan.

Harmita dan Radji, M. Kepekaan Terhadap Antibiotik. Edisi III. EGC. 2008.

KemenKes RI, 2012, Pedoman Pengendalian Infeksi Saluran Pernapasan Akut, Jakarta,Kementrian Kesehatan Republik Indonesia.

Kementrian Kesehatan RI, 2011. Profil Kesehatan Indonesia 2010.

Kementrian Kesehatan. Riset Kesehatan Dasar 2013. Jakarta: Badan Penelitian dan Pengembangan Kesehatan. 2013. 
Martin CR, Cloherty JP. Neonatal Hipernilirubinemia. Dalam: Cloherty Jp. Eichenwald EC, Stark AR, Penyunting. Manual of neonatal care. Edisi ke 5. Philadelphia: Lippincolt Wiliams \& Wilkins, 2004.

Notoadmodjo, S. Metodologi Penelitian Kesehatan. Jakarta: Rineka Cipta.2012.

Peraturan Menteri Kesehatan Republik Indonesia Nomor 2406/MENKES/PER/XII/2011 Tentang Pedoman Umum Penggunaan Antibiotik, 2011.

Proverawati, Atikah, Eni Rahmawati. Perilaku Hidup Bersih dan Sehat (PHBS). Yogyakarta: Nuha Medika. 2012.

Rudan, Igor., et al. 2008. Insidens global dan Asia Tenggara. Bulletin of the World Health Organization 2008; 86: 408-416.
Rustandi. ISPA Gangguan Pernafasan Pada Anak, Panduan bagi Tenaga Kesehatan dan Umum. Nuha Medika. Yogyakarta. 2011.

Santosa G, M.S Makmuri. Efektivitas dan Keamanan Cefixime pada Pengobatan Infeksi Saluran Pernafasan pada Anak. Cermin Dunia Kedokteran No. 101. Surabaya, 1995: 37-39.

Stiadi. Prosedur Penelitian Suatu Pendekatan Praktek. Rineka Cipta. 2007.

Sukarmin, dan Riyadi, Sujono. Asupan Keperawatan Pada Anak Yogyakarta: Graha Ilmu. 2009.

World Health Organization, 2001, WHO Model Prescribing Information Drug Use in Bacterial Infection, WHO, Geneva, 14-17.

World Health Organization. Pencegahan dan pengendalian ISPA di Fasilitas Pelayanan Kesehatan. 200 
